\title{
OBITUARIES
}

\section{Prof. J. F. Joliot, For.Mem.R.S.}

LE monde scientifique a été frappé par l'annonce de la mort de Jean Frédéric Joliot le 14 août à Paris.

Né le 19 mars 1900 à Paris, Frédéric Joliot a fait ses études d'ingénieur à l'École de Physique et de Chimie industrielles de Paris. Dans cette école il a pu profiter de l'enseignement de Paul Langevin, sur les conseils duquel il est entré en 1924 au Laboratoire Curie comme préparateur privé de Madame Pierre Curie.

Dans les premières années de son activité scientifique, Frédéric Joliot s'intéressait à la confection de minces écrans métalliques dans le but d'étudier leur conductibilité électrique. Depuis son mariage en 1926 avec Irène Curie, F. Joliot a commencé à s'intéresser aux problèmes de radioactivité et en 1930 il a soutenu sa thèse de doctorat ès sciences sur l'étude électro-chimique des radioéléments.

Esprit clair et méthodique il avait le don d'imaginer rapidement des expériences simples qu'il exécutait avec grande ingéniosité et habileté.

C'est entre 1932-34 qu'ensemble avec Irène Curie il a publié une suite de travaux remarquables qui dépassaient le cadre de la radioactivité proprement dite. En irradiant des cibles de glucinium par les particules $\alpha$ et en étudiant les radiations très pénétrantes signalées par Bothe et Becker en 1930, I. Curie et $\mathbf{F}$. Joliot ont observé un nouveau phénomène très surprenant : un écran de paraffine placé dans le trajet de la radiation pénétrante devenait lui-même le siège d'une émission de protons de grand parcours, qu'ils expliquaient comme un effet photoélectrique de photons d'environ $50 \mathrm{MeV}$. sur les protons. L'observation de la projection des protons était importante pour la découverte du neutron, signalé peu de temps après par J. Chadwick sur la base d'expériences plus détaillées sur d'autres noyaux légers projetés dans différents écrans par le glucinium irradié par les particules $\alpha$. Frédéric et Irène Joliot. Curie ont pu montrer à la suite le neutron était plus lourd que le proton.

Presque simultanément avec ces travaux I. Curie et F. Joliot ont fait des travaux importants sur l'annihilation du positon dans la rencontre avec un négaton et sur l'effet inverse, la création d'une paire négaton-positon dans la rencontre d'un photon $\gamma$ pénétrant avec un noyau atomique lourd.

La découverte la plus remarquable de Frédéric et Irène Joliot fut celle de la radioactivité artificielle, couronnée par le prix Nobel de chimie en 1935. En irradiant des métaux légers, comme par exemple l'aluminium, par les rayons $\alpha$, les époux Joliot ont observé que l'émission simultanée de neutrons et de positons cessait pour les neutrons, mais continuait à se produire pour les positons quand on enlevait la source $\alpha$. L'intensité de l'émission des positons décroissait avec le temps comme le ferait une source radioactive naturelle. E. Fermi et ses collaborateurs ont pu bientôt étendre la radioactivité artificielle aux éléments émetteur's de négatons en bombardant des noyaux légers ou moyens avec des neutrons lents.

F. Joliot a fait des contributions expérimentales élégantes à l'étude de la fission de l'urane après capture d'un neutron. Avec Halban et Kowarski il a annoncé que la fission de l'urane est accompagnée de l'émission d'environ trois neutrons, ce qui a laissé entrevoir la possibilité d'une réaction en chaîne et la libération massive de l'énergie nucléaire. En 1940, Frédéric Joliot fait venir en Angleterre son important stock d'eau lourde provenant de Norvège.

Joliot est élu membre de l'Académie des Sciences de Paris en 1943. Pendant plus d'un an il est directeur du Centre National de la Recherche Scientifique, et il est nommé Haut-Commissaire au Commissariat à l'Énergie Atomique en 1945, dont il doit abandonner la direction en 1950 pour des raisons politiques. En 1956 il succède à Irène Joliot-Curie comme professeur à la Sorbonne et il devient directeur du Laboratoire Curie et des Laboratoires de Physique Nucléaire nouvellement installés à Orsay, près de Paris.

Pendant l'occupation Frédéric Joliot a milité dans la résistance ; pendant plusieurs années il a été président du Conseil Mondial pour la Paix.

Frédéric Joliot avait des manières simples et il était d'un abord facile. Quoique très tourmenté intérieurement, il avait une nature gaie et il se liait facilement d'amitié. Un deuil cruel frappe sa fille Hélène Langevin son fils Pierre et ses proches.

S. Rosenblum

\section{Sir Douglas Mawson, O.B.E., F.R.S.}

WHEN towards the end of 1907 Ernest Shackleton passed through Australia on his way to the Southern Continent, the Australian Government gave him $£ 5,000$ towards the expenses of his venture, and in return he undertook to take Australian scientists with him. In doing so, they unwittingly turned the Pole-seeking quest of a gentleman adventurer into an expedition of major scientific importance. This same gift was also responsible for the introduction to polar exploration of the man who was destined to inspire and lead the first major Antarctic expedition in which adventure was subordinated to scientific inquiry. When Nimrod left Lyttelton, Douglas Mawson was a geologist already mature in experience and a lecturer in the University of Adelaide. In the next fourteen months he was destined to accompany his mentor, Edgeworth David, to the summit of Mt. Erebus through autumn frost and blizzard and to the South Magnetic Pole deep within the Antarctic plateau and back to the coast, a journey which involved well over a thousand miles of man-hauling of the severest kind.

Scott would have welcomed him on his final venture, but Mawson had finished with pole-seeking and had other fish to fry. In 1911 he left Australia with a well-found party sufficiently strong to man two bases the common objective of which was the scientific exploration and annexation of as much of the Antarctic coast south of Australia as could be covered in two years. With him he had the first air sledge and the first wireless installation ever to be established in Antarctica. In March 1913, this station, in spite of gales averaging 50 miles an hour for month on month-for he had chosen as his main headquarters the stormiest region of the whole landmass, where katabatic gales sweep downwards to the coast throughout the year-transmitted direct to Australia that first dramatic message recording Mawson's return from an ordeal I believe no other 
man I have known could have survived. After losing one companion and practically all the party's food down a crevasse and seeing a second companion die of starvation and over-exertion by his side, he cut his tent down to half a tent, his sledge down to half a sledge and trudged into his headquarters after three further weeks man-hauling alone on just enough food to keep body and soul together.

It is a measure of Mawson's courage and determination that his second enforced year's stay saw the carrying through of scientific work as fine in quality as that of the preceding year when all was going well. A stream of memoirs that kept the Australian Government Press busy off and on for forty years is one fitting tribute to an enterprise brilliantly planned and executed in the face of exceptional difficulties.

In the years following 1913 Mawson did outstanding work as field geologist and teacher; but Antarctic science remained a major interest throughout a long life that came to an end on October 15 . $\mathrm{H}_{\Theta}$ went to Antarctica again in 1929 and 1930, when he discovered MacRobertson Land, Queen Elizaboth Land and the Mackenzie Sea, using a seaplane to increase his range of action. Since the Second World War he has been a driving force behind the Australian Antarctic organization, A.N.A.R.E. When Prince Philip visited Australia in Britannia in 1956, it was Mawson who took the chair at the Antarctic symposium that was one important feature of the Melbourne programme, and the paper he delivered showed that his interest was as strong as ever and his intellect as keen. In courage, determination, singleness of purpose, breadth of scientific interest and quality of mind, he was Australian man at his best and he will be sorely missed. No one will regret his passing on more than the few surviving companions of his early adventurous days. Raymond Priestley

\section{Prof, F. A. Paneth, F.R.S.}

WORKERs throughout the world in many branches of science have learned with deep regret of the death in Vienna on September 17 of Dr. Friedrich Adolph Paneth, a director in the Max-Planck-Institut für Chemie in Mainz and emeritus professor of chemistry in the University of Durham.

Paneth was born in 1887 in Vienna, where his father was lecturer in physiology in the University. After studying science at the University of Vienna, he moved to Munich and, later, to Glasgow, where he worked for a year in the laboratory of Frederick Soddy. In 1912 he was appointed assistant at the Vienna Radium Institute, and six years later to a chair at the Prague Institute of Technology ; during the ensuing fifteen years he held similar posts in the Universities of Hamburg, Berlin and Königsberg. The events of 1933 in Germany caused him to leave that country and to seek refuge in London, where accommodation was found for him at the Imperial College of Science and Technology; the welcome he received there was later put on a more formal basis by his appointment to a readership in atomic chem. istry. In 1939, Paneth was appointed to the chair of chomistry at Durham, from which he retired in 1953 on reaching the age-limit. Even then he was not content to give up active scientific work, but returned to Germany to take up the post at Mainz which he held until his death.

Paneth's early education had been broadly basedto the end of his life he retained a keen interest in the humanities-and he was never in danger of too narrow a specialization in his work. His first major contribution, dating from his time at the Vienna Radium Institute, was made when he and Hevesy laid the foundations of the modern use of radioactive isotopes as tracers. At that time, of course, only lead and bismuth among the common elements were available in a usable radioactive form; but Hevesy and Paneth not only demonstrated that such materials could be used to follow the details of chemical reactions, but also went on to investigate in some detail the behaviour of trace quantities of such substances in precipitation, adsorption, electrochemical and colloid experiments.

After leaving Vienna, Paneth continued with this fundamental radiochemical work, but he was also led, by one of those almost accidental steps which not infrequently precede big developments in science, to the experiments which conclusively demonstrated the transitory existence of the simple aliphatic free radicals-perhaps his most important contribution to pure chemistry. He had been using the extreme sensitivity of the radioactive indicator technique to demonstrate the existence of the hydrides of lead and bismuth, and went on, with Fiofeditz, to examine the pyrolysis of tetramethyl lead carried, in a stream of hydrogen, rapidly through a heated quartz tube. They demonstrated, in a classic series of experiments, that the immediate products of the pyrolysis are metallic lead and free methyl radicals, and established a procedure that has since found wide use in studies of free radicals. During this period he was also refining the technique of measurement of the very small quantities of helium formed-as $\alpha$-particles -in radioactive decay processes. This work was continued after Paneth's arrival in Britain, and increasingly applied to the problem of 'age determination', especially of meteoritic materials. He began also to turn his attention to some chemical aspects of meteorology and, in collaboration especially with E. Glueckauf, much careful work was done on the concentrations of the minor constituents of the atmosphere.

On account of the second World War, Paneth achieved little in Durham until 1945, when he returned from Montreal, where he had spent two years with the joint British-Canadian Atomic Energy Laboratory to which he had been seconded. He was determined to set up in Durham a research laboratory devoted to radiochemical studies and, with characteristic indifference to the administrative difficulties of the immediate post-war period, he achieved his aim: the Londonderry Laboratory for Radiochemistry was formally opened in June 1947. Here the work on the rare gases, which was now Paneth's main interest, was pressed forward, with especially intensive work on the problem of the ages of meteorites. The atmospheric work was also continued, in collaboration with the U.S. Air Force, which carried out experimental rocket firings to obtain samples of air from very great heights for analysis.

Paneth was keenly interested in the history and philosophy of science (and, indeed, in philosophy in wider contexts) and was often consulted about the naming of newly discovered elements, and other questions of chemical nomenclature. As president (from 1949 until 1955) of the Joint Commission on Radioactivity of the International Council of Scientific Unions, he provided a useful link between the physical and chemical approaches to problems of standardization in radioactivity. In 1926 he had 